\section{AUTHOR}

Miguel A.

Montoya $^{1}$

Tecnológico de

Monterrey, Campus

Guadalajara

mmontoya@itesm.mx

1. Corresponding Author: Tecnológico de Monterrey, Campus Guadalajara; Av. General Ramon Corona 2514; Zapopan; Jalisco 45201; Mexico

\title{
International Joint Ventures among Developing Country Multinationals: The Case of Salinas Group-Faw*
}

AREA: 2 TYPE: Case

Joint Ventures Internacionales entre multinacionales de países en vías de desarrollo: El caso del Grupo Salinas-Faw

Joint Ventures Internacionais entre multinacionais de paises em desenvolvimento: O caso de Salinas Group-Faw

I study the determinants of the success of international joint ventures (IJVs) among developing country multinational companies. From the analysis of the case of the IJV between the Mexican conglomerate Salinas Group and the Chinese automobile producer FAW I conclude two points. First, IJVs among developing country firms reveal an implicit assumption of a tension due to belping an industry competitor and gaining market knowledge and technology. Second, IJVs among developing country firms reveal the unique challenge of having to face the perceived disadvantage of lower quality of products created by developing country firms.

Analizo los factores determinantes del éxito de las joint ventures internacionales (IJV, por sus siglas en inglés) entre multinacionales de países en vias de desarrollo. A partir del análisis del caso de las IJV entre el conglomerado mejicano Grupo Salinas y el fabricante chino de automóviles FAW, concluyo lo siguiente: primero, que las IJV entre empresas de países en vías de desarrollo revelan una asunción implícita de cierta tensión derivada de la ayuda a un competidor del sector y de la adquisición de conocimientos de mercado y tecnologia; y segundo, que las IJV entre empresas de países en vías de desarrollo revelan el único reto de tenerse que enfrentar a la desventaja percibida de contar con unos productos de calidad inferior creados por las empresas de paises en vias de desarrollo.

Estudei as determinantes do êxito de joint ventures internacionais (JVI) entre empresas multinacionais de países em desenvolvimento. A partir da análise do caso da JVI entre o conglomerado mexicano Salinas Group e o fabricante de automóveis chinês FAW, cheguei a duas conclusões. Primeiro, as JVI entre empresas de países em desenvolvimento revelam uma ideia implícita de tensão, por ajudar um concorrente da indústria, e ao ganhar conhecimento de mercado e tecnologia. Em segundo lugar, as JVI entre empresas de países em desenvolvimento revelam o desafio único de ter de enfrentar a desvantagem visivel da qualidade inferior dos produtos criados pelas empresas de países em desenvolvimento.

* I thank Alvaro Cuervo-Cazurra and anonymous reviewers for useful suggestions for improvement and Karla Navarro for excellent research assistance. I also thank Ricardo Salinas and the managers at Salinas Group and government officials from the State of Michoacán for the insights on the operations of the firm. All errors are mine.
DOI
RECEIVED
Accepted
10.3232/GCG.2012.V6.N1.02
03.05.2011
01.03.2012 


\section{Introduction}

I study the determinants of the success of international joint ventures (IJVs) among developing country multinational companies (DMNCs). Although there is a large literature analyzing IJVs (see reviews in Inkpen and Beamish, 1997; Parkhe, 1993; Reus and Rottig, 2009; Salk and Lyles, 2007), most of it has focused on studying IJVs with one partner coming from an advanced economy, the local partner being in a developing country, and both operating in the same industry. In this type of alliances, the implicit assumption is that the local partner provides the knowledge on how to navigate the challenging developing country conditions and gains expertise in technology, while the foreign partner provides the technological expertise and gains knowledge on how to operate in the developing country. This specialization in roles of partners operating in the same industry and the potential of strengthening a competitor, be it the foreign firm gaining a foothold in the developing country or the local firm upgrading its technology, has led researchers to caution about IJVs and the transfer of capabilities to competitors.

However, in contrast to these studies I focus on analyzing IJVs among developing country firms. These challenge the implicit assumption of the specialization of partners since neither partner may be at the technological frontier or lack knowledge on how to operate in developing countries. To gain a better understanding I study the case of the IJV between the Mexican conglomerate Salinas and the Chinese automaker FAW for the creation of a car assembly operation in Mexico in 2007. Although the IJV collapsed by 2009, it reveals several interesting ideas regarding the success of IJVs in general and IJVs among developing countries in particular. First, the case reveals a different logic of specialization since the two companies were operating in different industries and thus the fear of creating a competitor was not present. Instead, the two companies were truly specialized, one in the industry and technology and the other in the market access and navigation of institutional conditions. Thus, this created the opportunity for a deep collaboration and reduced the fear of helping a competitor. Second, external events led to the failure of the IJV as the partners could not solve the challenge of being developing country multinationals; the recession of 2008 and the perceived lower quality of cars created by developing country firms limited their ability to sell.

The paper thus contributes to the literature by providing a better understanding of some of the unique challenges that IJVs among developing country firms face that were little discussed in the literature before. In so doing, it identifies one implicit theoretical assumption of IJV studies: the tension between collaborating for mutual gain and the competition among firms operating in the same industry.

The paper is also useful for managers of developing country firms. It helps them better understand the benefits and challenges of establishing IJVs with other developing country firms. It encourages the specialization of the firms into market or technology to avoid the challenges of helping a competitor, but at the same time cautions about the challenges of undertaking IJVs with other developing country firms since these IJVs, although strategic and potentially profitable, suffer from the perception of lower quality of products generated by developing country firms.

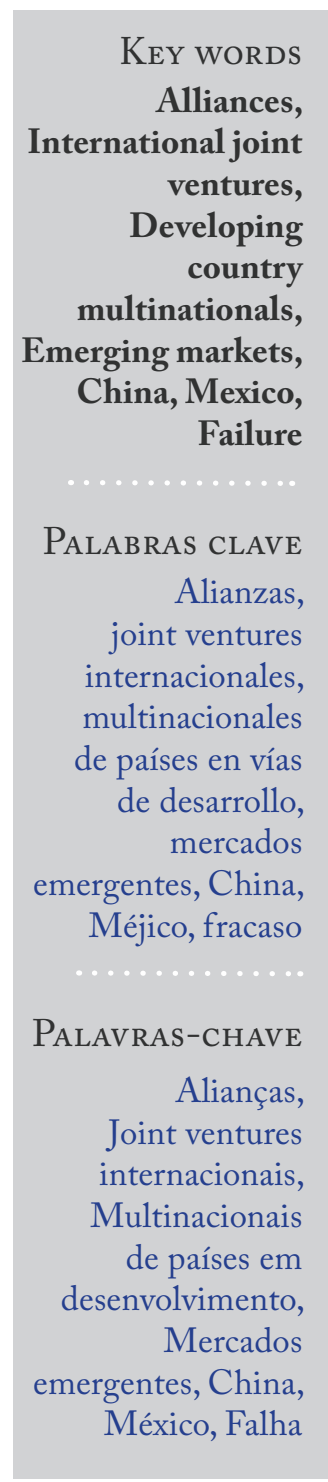

JEL CODES

M16; F23 
The rest of the paper is organized as follows. In the next section I describe the research design. I then present the case study. I conclude with the lessons from the case study.

\section{Research Design}

I analyzed the IJV between the Mexican conglomerate Salinas Group and the Chinese automaker FAW that was established in 2007 and lasted until 2009. In 2007 Ricardo Salinas, the president of Salinas Group, one of the largest business groups of Mexico, started negotiations with FAW, a leading Chinese car company, to import Chinese cars to Mexico as a first step towards the manufacturing of Chinese automobiles in Mexico.

I focus on this case study because it is one of the rare instances of IJVs between companies from developing countries. As a result, it can serve as a laboratory for better understanding IJVs, given that this literature has usually studied IJVs between a foreign partner that is an advanced economy firm and a local partner that is a developing or advanced economy firm, or among firms from advanced countries. In these cases, the foreign firm provides the technological sophistication while the local partner provides the access to the market; however, there is a tension in the relationship because the companies operate in the same industry and thus are helping competitors (see Brandenburger and Nalebuff 1996 for a discussion of co-opetition and the tensions).

With the help of a graduate assistant, I gathered public information on the IJV between the two firms and created a timeline of events, identifying the what, when, who, how and why of the actions taken. I conducted in-depth interviews lasting several hours with the owner of the group, Ricardo Salinas, and with Kathleen Ligocki, Salinas Motors Group's director in 2009. These interviews were complemented with a visit to the site of the plant and additional interviews with officials of the Michoacán Ministry of Economic Development, who requested to remain anonymous.

I then followed recommendations of Eisenhardt (1989) and Yin (1994) on how to structure the case study and analyze the information, going back and forth between case study materials and the literature to identify what is unique to this case that can inform theory directly. 


\section{IJV between Salinas Group and Faw to build Chinese Cars in Mexico}

\subsection{History of Salinas Group}

Salinas Group (SG) started operations in 1906 in Monterrey in the state of Nuevo Leon in Northern Mexico with a furniture factory that Benjamin Salinas opened with his brother-in-law Joel Rocha. In the 1920s, they established the first furniture store called Salinas y Rocha in downtown Monterrey, beginning with their sales system which consisted of microcredit with weekly payments. Different from other companies at the time, they not only sold furniture but also provided the credit to purchase the furniture. By the end of the 1920s they had three stores in the city. These two entrepreneurs understood the value of lending money in order to close the sales, and unknowingly created the business model that today underpins Elektra and Banco Azteca (Salinas Group, 2009).

In 1950 Benjamin Salinas' son, Hugo Salinas R., ventured into the business of manufacturing radios and televisions. In 1952 Hugo Salinas P., the grandson of the founders and son of Hugo Salinas R., was appointed general manager of the business. In 1959 the first store opened, which he named "Elektra", and there he orchestrated a scheme of credit buying and selling goods directly door to door. By 1968 Elektra had 12 stores in Monterrey. In 1976 the devaluation of the peso against the dollar forced the company to temporarily suspend its credit scheme, but it was then resumed until 1989.

In 1987 Hugo Salinas P. retired and named Ricardo Salinas, his son, as the new CEO of Grupo Elektra. In the middle of a strong economic crisis and facing the possibility of the bankruptcy of the business, Ricardo Salinas made a deep restructuration of the Elektra operations. He designed a new business model: low margins, an only cash payment policy and a basic product line. These measures radically changed the path of the company, which slowly but steadily returned to profitability in its operations. In 1993 the company started quoting in the Mexican Stock Exchange. In 1996 Elektra created "Dinero Express" (delivery \& payment system of money in Mexico).

As part of its strategy of meeting the lower segments of the population, in 2002 the group obtained a license to create Azteca Bank, which operates in the Elektra stores. In 2003 they also got permission to operate an Afore (management service retirement fund) which rounds out its financial services. In addition, Azteca Bank opened 813 branches in Grupo Elektra stores.

In 1993 a group of shareholders led by Ricardo Salinas made a successful bid for Imevisión public television network, changing the name to TV Azteca. By 1996 TV Azteca began to produce soap operas, establishing Digital Azteca and Azteca Music. In 1997 TV Azteca began quoting in the Mexican Stock Exchange and the New York Stock Exchange. By 2011 TV Azteca was the second largest Mexican television network after Televisa.

In 1998 Azteca TV made a strategic investment in Unefon, a wireless telephone services company. In 2003 the company acquired a stock majority in lusacell, which became the third largest mobile operator in Mexico, with approximately $7 \%$ of the mobile phone market in Mexico and a presence in $90 \%$ of the Mexican mobile market. 
As part of its expansion in Latin America, in 2005 the company began to franchise its brand Elektra. By 2010 it had 795 stores in Mexico. Between 1997 and 2010 the company expanded its operations in Latin America to 50 stores in Peru, 47 in Guatemala, 23 in Honduras, 12 in Panama, 13 in Argentina and 7 in Brazil.

\subsection{Building Chinese Cars in Mexico}

The entry into the car industry was an incremental process. In 2003, Elektra started selling automobile tires in its stores, and it became the third largest dealer in Mexico by 2010. In 2005 it started selling motorcycles in the Elektra stores under the brand name Italika; the motorcycles were Chinese made and sold under a brand owned by Electra. In three years they reached $56 \%$ of the total units sold in the country ${ }^{1}$.

The success of the experience selling motorcycles induced mangers to try to repeat it selling cars to people with low income who did not otherwise have access to the established brands. According to Javier Sarro, chairman of the transportation division of Salinas, it took two years of analysis and research. Thus this was not an improvised business for the company, and they visualized having the best after-sales service worldwide ${ }^{2}$.

In 2007 Salinas started a formal search for a Chinese partner to enter the car industry. The major Chinese manufacturers were: FAW, Geely, BAW Beijing Automobile Works, Beigi Futon Chery Automotive, Dongo Feng Motor, and Chana. Salinas had talks with over 10 manufacturers, but there was the most progress with Geely. However, after much analysis, the partnership with Geely did not come to fruition and instead Salinas partnered with FAW. The reason for selecting FAW as the best option was its resources and higher international experience. For Salinas, FAW was the best partner for the successful development of an automotive project.

\subsection{History of FAW}

First Automobile Works (FAW) was founded in 1953. In 1956, under the guidance of China's Central Committee and with assistance from the former Soviet Union, the construction of China's first automotive production base was completed. The period from the start of production in 1956 until the end of 1978 was a critical growth and development period for FAW. In 1978, reforms were initiated by the Chinese government to assist FAW and other state enterprises in catching up with the economic targets temporarily pushed back by the environment of the "Cultural Revolution". FAW pushed forward with new technology, tripling the number of product offerings and increasing production from 30,000 to 60,000 units. In Shanghai, FAW had a Development and Testing Center that was the leader in automotive research, was the largest in China, and was the only vehicle-testing center in the country for cold and semi-tropical climates.

1. Martinez (2007)

2. See interviews in Aviles (2007) and Hoyo (2007). 
During the 1983-88 period, the company based its new policies on moving the corporation away from the priorities of a traditional state-owned enterprise to that of a modern profitdriven organization. Profitability and sales growth were infused into the company culture. Taking a cue from overseas, many Japanese production techniques were incorporated into FAW's manufacturing process to enhance efficiency. With the support of China's Central Committee, FAW received enhanced rights for selling products through its proprietary sales channels and for overseas trade, and self-empowerment for enterprise planning. By 2010, FAW was present in Egypt, Iraq, Kenya, Pakistan, Russia, South Africa, Ecuador and Uruguay. The resulting new company atmosphere allowed FAW to follow the global trend in revising and replacing models at a much more rapid pace to meet increasing market demands. New light, medium and heavy trucks were planned in conjunction with a new range of automobiles.

In 1991 FAW created a joint venture with Volkswagen. In the period between 1991 and 2001 there were joint ventures formed with other foreign firms like Toyota and Mazda, Volkswagen and Audi. At the same time, FAW maintained its own brand of luxury models.

Its technology allowed the manufacture of cheap vehicles with basic standards worldwide. The United States, the EU and Japan adopted the NCAP (New Car Assessment Program) system, by which an authoritative institution or an industrial organization regularly conducted impact tests on new vehicles for sale in the market by applying standards more stringent than the safety regulations stipulated by the government. In China the level of safety standards was different. The China Automotive Technology and Research Center (CATARC) developed the C-NCAP, or China New Car Assessment Program, allowing for China's automotive standards and technological and economic development conditions. The distinct differences between countries in respect to the composition of the auto population, the typical types of impact accidents and the technical levels resulted in differences in the NCAP systems implemented by countries in terms of the organizing and implementing organizations, test items and test conditions. C-NCAP, too, was formulated on the basis of China's national conditions, road traffic conditions and accident analyses (China New Car Assessment Program, 2009).

\subsection{Mexican automobile industry ${ }^{3}$}

The automotive industry represented $3.5 \%$ of the Mexican economy and was the principal domestic manufacturing engine. Some 650,000 people worked directly in it, with 2.5 million people employed once machine shops, vulcanizing, parts stores, gas stations and toll booths are included. The role of the automotive industry in Mexico's economy was important because it affected other industries like glass, steel and rubber. In addition, this industry contributed significantly to job creation and attracting foreign direct investment. Transportation equipment manufacturing represented $19 \%$ of manufacturing GDP, exports of auto parts accounted for $12 \%$ of total exports, employment generated by the auto industry represented $13 \%$ of manufacturing employment and flows of foreign direct investment in auto parts were $15 \%$ of total FDI flows to the manufacturing industry.

3. All data from this subsection came from International Congress of the Automotive Industry in México (CIIAM). 
In 1999, Mexico was eleventh in world car production, competing with major producers such as Italy, Belgium and Brazil. The proximity to Mexico made the U.S. a major supplier of finished goods and intermediate products for the major automakers, as growing demand for the world's biggest market and dissatisfaction with working conditions in that country led U.S. companies to move to Mexico.

From 2004 to 2007, the demand for new cars exceeded one million sales in the country. This was considered a very positive market performance and suitable for the introduction of a product accessible to a social sector that was an untapped economic laggard in the market.

By 2007 Mexico produced about 2 million light vehicles, of which 1.5 million were exported. Vehicles produced in Mexico included the Chevy HHR crossover Chevrolet, the GM pickup trucks by Chrysler, the VW Beetle and Jetta, the Honda Accord, the Tiida, the Nissan Versa and Tsuru, and the Ford Fusion, Milan and Lincoln MKZ, among others.

In Mexico, 1.2 million vehicles entered with temporary permits or were legally imported. The marketing of these cars was informal and unfunded, and they are also generated high levels of pollution, with limited utility to generate jobs or investment and no income to the state or country. This was because there was an unmet demand in the market for the middle and lower class consumers, between 25 and 54 years of age, who represented $63 \%$ of the national population pyramid. Of these consumers $75 \%$ did not have a car, meaning 31 million were potential consumers who needed a cheap and reliable car.

The regulation of the industry affected its growth. In 1989, seeking to consolidate the export pattern of industry and looking for better expertise to compete internationally, a decree was enacted for the Promotion Automotive Industry Modernization, which entered into force in November 1990. This decree addressed a deficit in trade balance in the industry, which was mainly caused by its reliance on imported materials for assembly.

\subsection{Salinas Motors Group - FAW Business Plan}

Salinas and FAW signed a memorandum of understanding in 2007 to start marketing cars in Mexico by the first quarter of 2008 . They had a long-term project and plans to introduce a new line of automobiles in Mexico in order to reach a market that had not been explored and also to comply with safety standards and the emission control system to boost the automotive industry.

Initially the vehicles would be imported from China and it was projected that in three years they would be produced in Mexico. To produce the cars, a plant in Zinapécuaro in the state of Michoacán (West of Mexico) was planned. Its aim was to manufacture and export compact cars at affordable prices incorporating the national automotive parts suppliers. This plant was supposed to begin production by 2010 , so it could meet the increasing demand in the country. It was also intended to produce and export to Latin America, starting with countries where they already had a presence such as Brazil, Argentina, Guatemala, Peru, Honduras and Panama. FAW also had a particular interest in exploring the markets of USA and Canada. 
According to the National Auto Decree 2005, any company wishing to import vehicles into Mexico duty-free had to make a minimum investment of US $\$ 100$ million in a new plant with an output of 50 thousand vehicles per year. The Decree required that all imported automotive vehicles not manufactured in Mexico pay a fee. In the case of Chinese cars, this was $50 \%$ of the value of the unit. Applying such a tax made the consumer price unprofitable and uncompetitive. This is the reason why that Salinas Group and FAW were interested in producing in Mexico rather than merely importing Chinese cars.

The price of vehicles was set a little below the average of those sold in the country. The three models offered by FAW were the FI line (1.0-liter engine) in its sedan and hatchback versions; the F4 with 1.4-liter engine also had the same platform and basic versions and equipment. In addition, the F5 was offered in sedan and hatchback, although it was only available in the equipped version. The prices of the cars introduced in Mexico were: (1) F1 Hatchback Básico: US\$ 6,300; (2) F1 Hatchback de Lujo: US\$ 6,850; (3) F1 Luxury Sedán: US\$ 7,900; (4) F4 Sedán Base: US\$ 8,180; (5) F4 Sedán de Lujo: US\$ 8,815; (6) F5 Hatchback de Lujo: US\$9,536; and (7) F5 Sedán de Lujo: US\$10,4454.

FAW cars were sold under the weekly payment scheme commonly used in Elektra. Funding for the acquisition of the two models of FAW cars was granted by Azteca Bank with a down payment of 10 to $30 \%$ and interest rates ranging from $12 \%$ to $20 \%$, while Seguros Azteca (the insurance company of the Salina Group) would provide insurance. There were several financing schemes. For example, the F1 Hatchback, basic version, sold with $30 \%$ down and 60 months to pay and credits of US $\$ 30$ per week. Furthermore, this included vehicle maintenance. For US $\$ 4.50$ more per month, the insurance of the unit was covered. The rate charged on credit was around $20 \%$ annually and was provided by Azteca Bank.

On November 23 $3^{\text {rd }}, 2007$, with the presence of the President of Mexico, Felipe Calderon; President of Salina Group, Ricardo Salinas; President and CEO of FAW, Zhu Yan Feng; and Michoacán governor, Lázaro Cárdenas, the first stone was placed where the FAW automobile assembly plant was supposed to be built in Zinpapécuaro, Michoacán. This was applauded by the federal agent after pointing out that the strategic alliance between Salina Group and one of the biggest car producer in China would generate about 2,000 direct jobs and about 14,000 indirect jobs. This started a new stage that was to be the largest investment from China in Mexico to date. In the opening ceremony, Felipe Calderon said that the automaker would benefit the social sectors with little chance of getting a car, since they would be able to acquire one at modest prices.

Ricardo Salinas explained that as a first step the vehicles would come from China and that in three years they would be produced in Mexico. Once the assembly plant was built, it would have a production capacity of one hundred thousand cars annually. Ricardo Salinas added: «Today is an important day for Salinas Group because we started a business line that we do not know, we will learn and we will do a lot of cars and very well done». Ricardo Salinas said that for Mexico this was a very important investment, because a Chinese company was seeing the country as a very good area for investment. He thanked the General President of FAW Group, Zhu Yanfeng, which took into account the Mexican entrepreneurs.

4. Original prices in Mexican Pesos (exchange rate: MXP 11 per US\$ 1) at http://www.elektra.com.mx/ 
The assembly line in the town of Zinapécuaro was to have an initial investment of US\$ 150 million. Then it was expected to have an additional US\$100 million investment in order to have a distribution network and service workshops. Thus the total investment would add up to more than US\$250 million.

Salinas and FAW Group considered that in order to be competitive in the segment of inexpensive cars, they must generate high production volumes. Therefore, they would need a second phase to bring the plant's capacity to 200,000 units per year, considering both domestic and export markets. This second phase was to include a body-stamping process. The Automotive Plant had two access paths, one from Mexico-Guadalajara Highway, and the other from the old road to Zinapécuaro, Michoacán, which connected to the port and thus allowed for an easy export.

On April $7^{\text {th }}, 2008$, as part of the plant project, the FAW Group President Wang Gang and the President of Salinas Group Motors Javier Sarro signed a commitment letter in order to create a research and development center. The main objective of this center was to link the education sector with the activities of the vehicle assembly plant. At this event the Minister for Economic Development, Eloy Vargas, announced that universities were presented with the model of placement of students with the productive sector. This program sought to link careers to the needs for the Center for Automotive Technological Innovation and Development to produce cars in Mexico designed by Mexicans with Chinese technologies. Vargas said the graduating skilled labor from Universities will contribute to the development of Michoacán ${ }^{5}$.

The Ministry for Economic Development of Michoacán explained that both companies intended to set up R\&D laboratories in Mexico. The main objective was the designing of vehicles and bodies for markets in Mexico and Latin America (Panama, Guatemala, Honduras, El Salvador, Brazil, Peru and Argentina). Likewise, the estimated investment for the construction of this center of research and development was US\$12 million. Among the benefits for Michoacán from the investment, the government of Michoacán found: triggering the industrial development of the state; anchoring the new industrial zone in the state; increasing more than $5 \%$ of the economically active population; creating a center of research and development of world class body design; and being China's largest investment state receptor in the country.

This strategic project was crucial in the industrial development of Michoacán, promoting the opportunity to move into the automotive sector. This was one of the segments of the heavy and technology industries that was most likely to generate economic income and jobs, attracting investment through plants that generate and require the products and services of local companies. All of these characteristics facilitated an increase in job creation and in the generation of new poles of development. All these concepts and the need for national components for automobile assembly opened the door for the consolidation of the automotive cluster. Additionally, they also triggered the creation of a research and development center, which would help attract companies that are specialized in the field. This promoted the consolidation and positioning of the State of Michoacán as the best option in the sector given its geographical location, logistics and technology. In the same way, all the above would contribute to developing local talent through linkage programs with 12 universities in 
the state of Michoacán; additionally, a 5\% increase in the GDP of Michoacán was expected as the home of the popular car in Mexico and Latin America.

In 2007, officials from the Ministry of Economy authorized the importation of approximately 5,000 vehicles from the F1 and F5 models from China, which arrived in the country in October 2007. The cars were disembarked in December of that year, at the port of Lázaro Cárdenas Las Truchas, Michoacán in Mexico's Pacific coast. These remained on board until they got a permit to be released, and were commercialized from mid-January in the company stores, mainly in the Federal District and the central states of Mexico and Morelos. They were also sold in the western state of Michoacán and Guerrero, a state from the southeast of Mexico.

\subsection{External Shock: Economic Crisis}

The U.S. economic crisis, the international economic recession, unemployment and the crisis being experienced by the global automotive industry negatively affected the mood of consumers in an atmosphere of uncertainty. All these factors made it difficult to invest in the purchase of a vehicle or other high-cost product.

According to The International Organization of Automobile Manufacturers (IOCA) the volume of world production in 2008 declined $4.1 \%$ over the previous year. The Mexican Association of the Automotive Industry (Asociación Mexicana de la Industria Automotriz, AMIA, 2009) announced that in the first quarter of $2009,246,878$ vehicles were sold, 100,182 fewer than were sold in the same period the year before. The AMIA attributed the lack of credits to job insecurity and to the drastic drop in sales. But to these must be added the general rise in prices for cars, as well as the constant increase in gasoline prices, the crushing taxes that raise prices of vehicles (VAT, ISAN, tenencia which is an annual payment for having a vehicle), and payments services such as verification, plates and insurance against theft and accidents. Consumers, fearful of adversity, stopped buying cars and new vehicle sales in December fell nearly $20 \%$, and closed the year with a contraction of $6.8 \%$. Recent analysis from Frost \& Sullivan "How the Economic Crisis is Affecting the Passenger and Light Commercial Vehicle Market in Mexico" revealed that the market sold 1,025,520 units in 2008 and it was estimated to be reduced by approximately 175,500 units in 2009 due to the economic crisis.

In 2007, Mexico's automobile credit fell one percent, while in 2008 it decreased by 12 percent. It is not just financial institutions that are reluctant to provide credit, but also the automotive and banking institutions who are also putting restrictions on lending money. Mexico's federal government gave the automobile industry a rescue package to stay afloat in these difficult conditions. For example, the Technical Stoppage Program developed by the Mexican government helped about 60 major companies related to the automotive industry, and was designed to help companies through the third payment of salaries to avoid layoffs. 


\subsection{Dissolution of Agreement}

During the partnership between Salinas Group and FAW between 2008 and 2009, about 5,000 FAW cars were sold in Mexico. By February 2010, Salinas Group announced the end of the partnership with FAW and its automotive operations. «l believe that this world does not need another (automotive) plant», said Ricardo Salinas on April $12^{\text {th }}, 2009$, when he announced the suspension of the construction of the FAW factory in Mexico. In his opinion, the Mexican market did not provide the same growth prospects and economics of scale for the business.

Several problems limited the success of the alliance. First, at the macroeconomic level, the international economic recession and the crisis being experienced by the global automotive industry scuttled the plans of the Salinas Group-FAW project in Mexico. FAW found a great deal of mistrust and low acceptance of its products by Mexican consumers, leading to a reduction in the supply of vehicles in the current year. These factors also lead to a delay in the investment for the assembly plant in national territory.

Second, at the industry level, there was very strong competition and the cars sold were not as competitive as thought. As Salinas realized, the Mexican automotive market was quite mature, there were a variety of cars at all price levels (Chrysler, Ford, General Motors, Nissan, Volkswagen, BMW, Honda, Toyota, Peugeot, Renault, Suzuki, Fiat, Subaru, Mercedes Benz, Jaguar, Mazda and Volvo, among others, have a presence in the Mexican market) so it was difficult to participate in the market with a car from a country with little automotive tradition and with a perception of poor quality.

Salinas also found that the inexperience of FAW for export, since they only had experience in developing countries with less sophisticated automotive markets, was a barrier to business growth. FAW had no experience in the selling and marketing of cars in markets with high competition. In the Chinese automotive market in the last two decades, the local demand for vehicles had always grown at a higher rate than the supply.

Another weakness of the alliance Salinas Group-FAW was that the price of cars was not much lower than its competitors (only 5 to $7 \%$ lower than a GM-Chevy, for example). Salinas thought that their own credit through the Azteca Bank and the insurance of the same company would be enough to make FAW cars attractive in the Mexican market. But other automakers' distributors also had their own, very competitive, credit system. Also, in Mexico, bank and savings houses' credit to buy new cars were popular. Furthermore, in Mexico any new reduced-price compact car had very strong competition in the imported used cars from the neighboring U.S., which had a low price and often do not require the payment of all the taxes and insurance for circulation. Finally, Salinas failed to sell FAW cars to buyers groups, such as taxi companies or syndicates, local or state government or large companies (except their own, like TV Azteca).

Third, at the firm level, the commercialization of automobiles by Salinas Group also faced a challenge of infrastructure and logistics. Unlike motorcycles, cars could not be sold at the Elektra store which offered appliances or furniture. The sale of vehicles required the creation of a network of distributors and mechanical workshops separate from Elektra stores. Those new car stores increase the fixed costs of the operation. 
Furthermore, the cars did not meet Department of Transportation safety and pollution standards in the United States, a market that they wanted to access from Mexico. Due to this, FAW did not put much effort into the partnership with Salinas Group, as they found the Mexican market came with high competition. On the other hand, demand for automobiles in China continued to grow, causing FAW to focus on its domestic market. This, along with the crisis in the North American automotive industry and the boom of their business in China, made the FAW partners give little attention and effort to the Mexican adventure.

\section{Conclusions}

The case supports the idea that specialization is good and thus does not create problem of competition. It initially appeared that there was a good complementarity between partners. FAW was a specialist in the mass production of cars at affordable prices in China and Salinas Group was a specialist in the sale of goods on credit to the middle and lower-middle class of Mexico and other Latin America markets. The case reveals a different style of specialization since the two companies were operating in different industries and thus the fear of creating a competitor was not present. As mentioned, the two companies were truly specialized, one on the industry and technology and the other in the market access and navigation of institutional conditions. Thus, this created the opportunity for a deep collaboration.

A lesson for managers of emerging country firms is that unlike other consumer products that can be imported from low cost regions (China, Southeast Asia, India), importing durable goods, where a popular and renowned brand and its local distributors are important because of the high price (more than fifteen months of household income) and regular maintenance, is more difficult. The market introduction of these goods in a competition with developed countries' multinationals is challenging and requires different strategies than those used for selling consumer goods (less than three months of household income) with no substitutes and perception of better quality-price relation.

Being developing country firms, they do not solve the perception that products are of lower quality. The perception of low quality of the goods imported from a developing country multinational company in a market with competition from large multinational firms from developed countries, along with the inexperience of the local partner in that specific market, where its competitive advantages (existing stores and immediate credit) was not valuable, leads to a failure of the association. Some of the most notable challenges that the alliance between Salinas Groups and FAW faced were: (i) FAW cars were not high quality, even though they were acceptable for small markets (Libya, Iran, Syria, Ecuador, etc.); (ii) the sale of the cars required new sales and service spaces; (iii) there were no interested buyers groups (taxis, government or business); (iv) communication between the parties was not good; and (v) the economic crisis being experienced by the global automotive industry negatively affected the mood of consumers in an atmosphere of uncertainty. Thus, the case cautions about the challenges of undertaking IJVs with other developing country firms since these IJVs, although strategic and potentially profitable, suffer from the perception of lower quality of products generated by developing country firms. 


\section{References}

Asociación Mexicana de la Industria Automotriz, AMLA (2009). Estadísticas 2009. Asociación Mexicana de la Industria Automotriz. http://wwww.amia.com.mx/estadisticasum.html. Accessed on April, 15 $15^{\text {th }}, 2010$.

Aviles, R. (2007). Comercializará Elektra autos chinos. Mural, December, 1th. www.mural.com. Accessed on May, $15^{\text {th }}$, 2009.

Brandenburger, A. and Nalebuff, B. (1996). Co-opetition. New York: Broadway Business.

China New Car Assessment Program (2009). Document. http://www.c-ncap.org/C-NCAP/index. htmbttp://www.c-ncap. org/C-NCAP/index. btm . Accessed June, $20^{\text {th }}, 2009$.

CNN Expansión (2009). Reversa a planta de Salinas Motors en Michoacán. CNN Expansion, April 13 th. http://blogs. cnnexpansion.com/informacion-privilegiada/2009/04/13/reversa-a-planta-de-salinas-motors-en-michoacan/. Accessed June, $20^{\text {th }}, 2009$.

Congreso Internacional de la Industria Automotriz en México, CILAM (2008). bttp://www.ciiam.com/graficas/cifras2009. pdf. Accessed September, $13^{\text {th }}, 2009$.

Eisenhardt, K. M. (1989). Building Theories from Case Study Research, Academy of Management Review, 14 (4): 532-550.

Estrada, A. (2008). Generará planta automotriz 12 mil empleos: Sedeco. Reporte Digital, Agencia de Noticias de Michoacán, January, 21 $1^{\text {th }}$. http://wwww.reportedigital.com.mx/noticias/negocios/10134.html. Accessed June, $20^{\text {th }}, 2009$.

Frost E Sullivan Research Service (2009) How the Economic Crisis is Affecting the Passenger and Light Commercial Vehicle Market in Mexico. Frost E Sullivan Research Service, June, $4^{\text {th }}$ http://www.frost.com/prod/servlet/report-brochure. pag? id=N61D-01-00-00-00. Accessed on April, 4th, 2011.

Hoyo, R. (2007) Llegaron los autos Chinos FAW de la mano de Grupo Salinas. Autocosmos, December, $4^{\text {th }}$ http://noticias.autocosmos.com.mx/2007/12/04/llegaron-los-autos-chinos-faw-de-la-mano-de-grupo-salinas. Accessed on May, 15 th, 2009.

Inkpen, A. C. and Beamish, P. W. (1997). Knowledge, bargaining power, and the instability of international joint ventures. Academy of Management Review, 22 (1): 177-202.

International Organization of Automobile Manufacturers, IOCA (2009). Production Statistics 2008. http://oica.net/category/production-statistics/2008-statistics/Accessed on April, 15 th, 2010.

Martinez, J. (2007). Autos chinos desde 350 pesos semanales. CNN-Expansión November, 30th. http://www.cnnexpansion. com/negocios/2007/11/29/autos-chinos-desde-350-pesos-semanales. Accessed May, $15^{\text {th }}, 2009$.

Parkhe, A. (1993). «Messy» research, methodological predispositions, and theory development in international joint ventures. Academy of Management Review, 18 (2), 227-268.

Reus, T. and Rottig, D. (2009). Meta-analyses of International Joint Venture Performance Determinants. Management International Review, 49 (5): 607-640.

Salinas Group (2009). Ricardo Salinas web. https://www.ricardosalinas.com/bio/es/benjamin salinas westrup.htm. Accessed May, $7^{\text {th }}, 2009$.

Salk, J. and Lyles, M. A. (2007). Gratitude, nostalgia and what now? Knowledge acquisition and learning a decade later. Journal of International Business Studies, 38 (1): 19-26.

Yin, R. K. (1994). Case Study Research. Design and Methods. London: SAGE. 